\title{
Monophyly and phylogenetic origin of the gall crab family Cryptochiridae (Decapoda : Brachyura)
}

\author{
Sancia E. T. van der Meij ${ }^{\mathrm{A}, \mathrm{C}}$ and Christoph D. Schubart ${ }^{\mathrm{B}}$ \\ A Department of Marine Zoology, Naturalis Biodiversity Center, Darwinweg 2, 2333 CR Leiden, The Netherlands. \\ ${ }^{B}$ Biologie 1, Institut für Zoologie, Universität Regensburg, D-93040 Regensburg, Germany. \\ ${ }^{\mathrm{C}}$ Corresponding author. Email: sancia.vandermeij@naturalis.nl
}

\begin{abstract}
The enigmatic gall crab family Cryptochiridae has been proposed to be phylogenetically derived from within the Grapsidae (subsection Thoracotremata), based on the analysis of 16S mtDNA of one cryptochirid, Hapalocarcinus marsupialis, among a wide array of thoracotremes, including 12 species of the family Grapsidae. Here, we test the monophyly and phylogenetic position of Cryptochiridae using the same gene, but with an extended representation of cryptochirids spanning nine species in eight of 21 genera, in addition to further thoracotreme representatives. The results show that gall crabs form a highly supported monophyletic clade within the Thoracotremata, which evolved independently of grapsid crabs. Therefore, the Cryptochiridae should not be considered as highly modified Grapsidae, but as an independent lineage of Thoracotremata, deserving its current family rank. Further molecular and morphological studies are needed to elucidate the precise placement of the cryptochirids within the Eubrachyura.
\end{abstract}

Additional keywords: 16S mtDNA, coral-associated organisms, evolutionary origin, superfamily.

Received 20 December 2013, accepted 26 June 2014, published online 13 November 2014

\section{Introduction}

Gall crabs (Cryptochiridae) are obligate symbionts of living scleractinian corals, residing in galls, tunnels or pits in the coral skeleton. The family consists of 21 genera and 49 species (Ng et al. 2008; Davie 2014) and is recorded from both shallow and deeper waters down to $512 \mathrm{~m}$ (Kropp and Manning 1987; Kropp 1990). The first known gall crab species was described by Stimpson (1859), who named the species Hapalocarcinus marsupialis and referred to it as 'a remarkable new form of Brachyurous Crustacean'. Stimpson did not assign $H$. marsupialis to a crab family, but remarked that - in the series - it would probably fit between Pinnotheres and Hymenosoma, which belong to the Pinnotheridae De Haan, 1833 and the Hymenosomatidae MacLeay, 1838, respectively. Heller (1861) described a second gall crab species, Cryptochirus coralliodytes, and commented on its similarities with Ranina and Notopus (Raninidae De Haan, 1839). A. Milne-Edwards (1862) described yet another species, Lithoscaptus paradoxus, mentioning that this new species did not fit in any of the known crab families. Paul'son (1875) subsequently erected the subfamily Cryptochirinae within the Pinnotheridae to accommodate the gall crabs, which Richters (1880) elevated to family level. A more complete overview of the history of the family Cryptochiridae Paul'son, 1875, can be found in Kropp and Manning (1985).

Close phylogenetic affinities between the Cryptochiridae and Grapsidae s.str. (cf. Schubart et al. 2002) were proposed by
Wetzer et al. (2009). The authors recommended dropping the superfamily Cryptochiroidea (see $\mathrm{Ng}$ et al. 2008) and suggested considering Cryptochiridae as just one of many separate 'grapsoid' families. The zoeal features of Cryptochiridae present numerous traits that are unique within the Brachyura (Tudge et al. 2014 and references therein). Based on the larval development, a close relationship between grapsids and cryptochirids had been proposed by Fize (1956), who regarded cryptochirids as a transitional group between Grapsidae s.l. and Calappidae. Fize and Serène (1957) deviated from this placement and argued that Cryptochiridae has closest affinities with Pinnotheridae, based on the morphology of the female abdomen. When considering the larval morphology (based on Troglocarcinus corallicola Verrill 1908), cryptochirids also appear closely related to Pinnotheridae, with close affinities to Hymenosomatidae and Leucosiidae (Scotto and Gore 1981). Utinomi (1944) had previously considered the zoea of Hapalocarcinus and Cryptochirus to belong to the so-called Grapsizoea (including genera of the Cancridae, Grapsidae, Xanthidae and some Oxyrhyncha) and dismissed suggestions of a close affinity of Cryptochiridae with Pinnotheridae. Affinities with several other crab families (Hymenosomatidae, Leucosiidae, Pinnotheridae, Palicidae and Retroplumidae) were discussed by Kropp (1988), who suggested monophyly of the Cryptochiridae based on a series of unique morphological characters (gastric mill, lateral lobe of the antennule, lack of mandibular palp). Guinot et al. (2013), based on several morphological structures, also 
concluded that the cryptochirids form a monophyletic group. The spermatozoa of $C$. coralliodytes and $H$. marsupialis were studied by Jamieson and Tudge (2000) and share a striking synapomorphy that is unique for the family Cryptochiridae (Tudge et al. 2014). Tudge et al. (2014) also compared the sperm ultrastructure and operculum of Cryptochiridae to those of species belonging to the Majoidea and the Hymenosomatidae. The sperm ultrastructure proves to be somewhat equivocal with regard to placement of the cryptochirids in Thoracotremata or Heterotremata. The morphology of the female reproductive system was studied by Vehof et al. (in press) who showed that the Cryptochiridae share characteristics with the thoracotreme families Varunidae, Ocypodidae and Pinnotheridae. The cryptochirid reproductive system is nevertheless remarkable in having ovaries that are expanded into the abdomen (=pleon), which is exceptional among Brachyura and has only been known from pinnotherids so far (Becker et al. 2011).

In the most recent treatments of the Brachyura (Ng et al. 2008; De Grave et al. 2009; Ahyong et al. 2011; Tsang et al. 2014), the Cryptochiridae is classified in the superfamily Cryptochiroidea, and placed in the subsection Thoracotremata. The main argument to place Cryptochiridae in the Thoracotremata is the sternal location of male gonopores (Guinot 1977). This is in agreement with Scotto and Gore (1981), who regarded adults of the Atlantic species Troglocarcinus corallicola as exhibiting an advanced thoracotreme state. The Cryptochiridae have alternatively also been considered Heterotremata (e.g. Guinot and Richer de Forges 1997; Guinot and Bouchard 1998), advanced Heterotremata (Martin and Davis 2001) or a 'basal heterotreme eubrachyuran superfamily' (Guinot et al. 2013). Indeed, in the first paper employing molecular data to clarify the position of the gall crabs within other brachyurans, its placement in the subsection Thoracotremata was confirmed (Wetzer et al. 2009).

The monophyly and phylogeny of the Cryptochiridae among the Thoracotremata were re-evaluated by using $16 \mathrm{~S}$ mtDNA data for 10 gall crab species belonging to nine genera. We reused almost the entire dataset from Wetzer et al. (2009), but expanded it by adding 10 gall crab sequences, and 24 additional sequences from thoracotreme crab species and families not included in the previous study. We used this enlarged dataset for analysis of the position of the Cryptochiridae within the Thoracotremata and to test Wetzer et al.'s result that Hapalocarcinus marsupialis evolved from within the family Grapsidae.

\section{Materials and methods}

Wetzer et al. (2009) used two 16S mtDNA sequences of Hapalocarcinus marsupialis, combined with 49 GenBank sequences of thoracotreme species and four heterotreme species as outgroup to evaluate the relationships between Cryptochiridae and other Brachyura. To re-evaluate the position of the Cryptochiridae, we added nine additional species belonging to eight cryptochirid genera (see Fig. 1). We based our identifications on Fize and Serène (1957), Kropp $(1989,1990)$ and van der Meij (2012). We included one additional sequence of $H$. marsupialis for comparison with the material of Wetzer et al. (2009).
An enlarged dataset encompassing a minimum of two species of all known thoracotreme families was used as a more complete dataset for research on the phylogenetic position of the gall crabs. Type genera and species were included whenever the corresponding data were available in GenBank. The full list of GenBank sequences and species authorities can be found in Table 1.

The following changes and additions were made in comparison to the dataset of Wetzer et al. (2009):

(1) The Old World freshwater crabs used by Wetzer et al. (2009), Sartoriana spinigera (Gecarcinucidae) and Geothelphusa pingtung (Potamidae), were moved to the ingroup together with additional freshwater crabs from other continents, while Crossotonotus spinipes (Crossotonotidae) and Palicus caronii (Palicidae) were kept as outgroups. This was done in consequence to the newest brachyuran phylogeny by Tsang et al. (2014), which shows that Old World freshwater crabs of the superfamily Potamoidea (see Klaus et al. 2009) are placed at the base of the Heterotremata which in turn are the sister group to all Thoracotremata. This implies that the Potamoidea are phylogenetically closer to Thoracotremata than most other Heterotremata are to Thoracotremata. Furthermore we wanted to root the tree in a comparable way to previous phylogenies of the Thoracotremata (Schubart et al. 2000, 2002, 2006).

(2) Sesarma windsor (Sesarmidae) was deleted from the dataset as it is a close sister species of S. meridies (see Schubart and Koller 2005) and does not contribute to the phylogenetic diversity, whereas Sesarmoides longipes (Sesarmidae) was removed, as it is a very basal sesarmid that often clusters weakly (see Schubart et al. 2002) and will be dealt with separately. Instead, the type species of the family, Sesarma reticulatum, was added, as well as the Asian sesarmid representative Chiromantes haematocheir.

(3) Hemigrapsus oregonensis (Varunidae) was removed from the dataset, as it is not a typical representative of the genus, and will probably be placed in a separate genus after revision.

In addition to these changes, we noticed that GenBank no. AB002125 (Wetzer et al. 2009: table 2) does not correspond to Scopimera globosa (De Haan, 1835), but to S. bitympana (Dotillidae). We used the latter in our analyses. Taxon selection for the enlarged dataset was also tested with species belonging to heterotreme families, but in all preliminary analyses the cryptochirids consistently nested in the Thoracotremata, similar to the results of Wetzer et al. (2009). Furthermore, several potential outgroups were tested.

\section{Collecting}

The gall crabs, with the exception of Cryptochirus coralliodytes, were collected in Indonesia (Raja Ampat, Papua; Ternate, Halmahera) and Malaysia (Semporna, E Sabah) by the first author from 2007 to 2010. Corals were searched for galls and pits, and subsequently split with hammer and chisel. The gall crabs were preserved in $80 \%$ ethanol, after being photographed with a digital SLR camera equipped with a $50 \mathrm{~mm}$ macrolens. The material is deposited in the collections of Naturalis in Leiden, The Netherlands (formerly Rijksmuseum van 


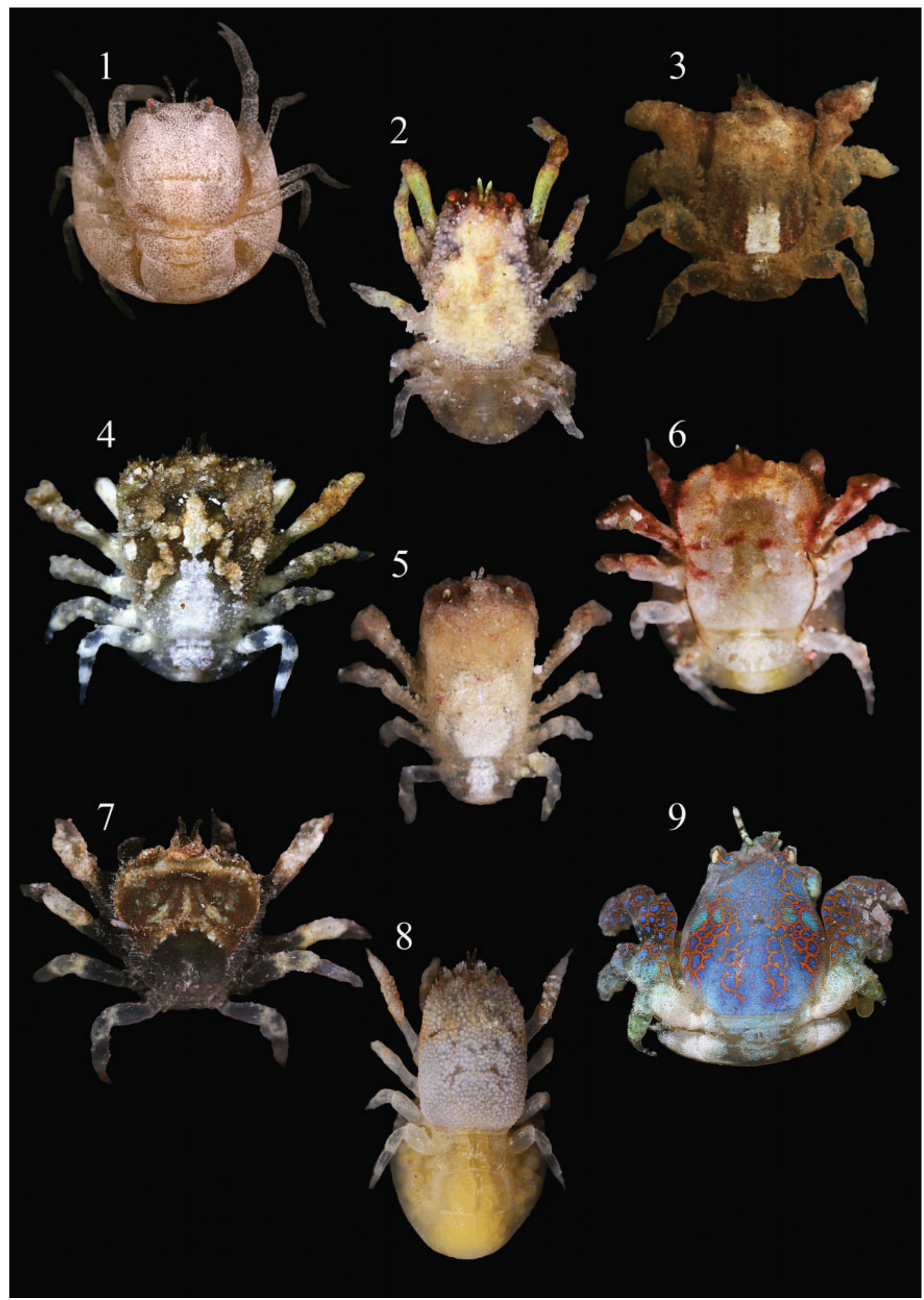

Fig. 1. The cryptochirid taxa used in this study: (1) Hapalocarcinus marsupialis; (2) Utinomiella dimorpha; (3) Opecarcinus lobifrons; (4) Fungicola utinomi; (5) Dacryomaia sp.; (6) Fungicolafagei; (7) Fizesereneia sp.; (8) Lithoscaptus tri; (9) Pseudocryptochirus viridis. No picture is available for Cryptochirus coralliodytes. Not to scale. 
Table 1. GenBank sequences used in molecular analyses (taxonomic authorities based on Ng et al. 2008) * = sequences used in this study, but not included in Wetzer et al. (2009)

\begin{tabular}{|c|c|c|}
\hline Family & Species & GenBank No. \\
\hline \multirow[t]{2}{*}{ Camptandriidae } & Baruna trigranulum (Dai \& Song, 1986) & AB002129 \\
\hline & Paracleistostoma depressum De Man, 1895 & AB002128 \\
\hline Crossotonotidae & Crossotonotus spinipes (De Man, 1888) & AJ130807 \\
\hline \multirow[t]{12}{*}{ Cryptochiridae } & *Cryptochirus coralliodytes Heller, 1861 & KM114587 \\
\hline & *Dacryomaia sp. & KM114582 \\
\hline & *Fizesereneia sp. & KM114581 \\
\hline & *Fungicola fagei (Fize \& Serène, 1956) & KJ923707 \\
\hline & *Fungicola utinomi (Fize \& Serène, 1956) & KM114583 \\
\hline & Hapalocarcinus marsupialis Stimpson, 1859 & EU743929 \\
\hline & Hapalocarcinus marsupialis Stimpson, 1859 & EU743930 \\
\hline & *Hapalocarcinus marsupialis Stimpson, 1859 & KM114586 \\
\hline & *Lithoscaptus tri (Fize \& Serène, 1956) & KM114584 \\
\hline & *Opecarcinus lobifrons Kropp, 1989 & KJ923730 \\
\hline & *Pseudocryptochirus viridis Hiro, 1938 & KJ923710 \\
\hline & *Utinomiella dimorpha (Henderson, 1906) & KM114585 \\
\hline \multirow[t]{4}{*}{ Dotillidae } & Dotilla wichmanni De Man, 1892 & AB002126 \\
\hline & Ilyoplax deschampsi (Rathbun, 1913) & AB002117 \\
\hline & *Scopimera bitympana Shen, 1930 & $\mathrm{AB} 002125$ \\
\hline & Tmethypocoelis ceratophora (Koelbel, 1897) & $\mathrm{AB} 002127$ \\
\hline \multirow[t]{4}{*}{ Gecarcinidae } & Cardisoma carnifex (Herbst, 1796) & AM180687 \\
\hline & *Discoplax hirtipes (Dana, 1852) & FM863830 \\
\hline & Gecarcinus lateralis (Fréminville, 1835) & AJ130804 \\
\hline & Gecarcoidae lalandii H. Milne Edwards, 1837 & AM180684 \\
\hline \multirow[t]{3}{*}{ Gecarcinucidae } & *Holthuisana biroi (Nobili, 1905) & FM180132 \\
\hline & *Lepidothelphusa cognetti (Nobili, 1903) & FM180134 \\
\hline & Sartoriana spinigera (Wood-Mason, 1871) & AM234649 \\
\hline \multirow{2}{*}{ Glyptograpsidae } & Glyptograpsus impressus Smith, 1870 & AJ250646 \\
\hline & Platychirograpsus spectabilis De Man, 1896 & AJ250645 \\
\hline \multirow[t]{15}{*}{ Grapsidae } & Geograpsus lividus (H. Milne Edwards, 1837) & AJ250651 \\
\hline & Goniopsis cruentata (Latreille, 1803) & AJ250652 \\
\hline & Grapsus grapsus (Linnaeus, 1758) & $\mathrm{AJ} 250650$ \\
\hline & Leptograpsus variegatus (Fabricius, 1793) & AJ250654 \\
\hline & Metopograpsus latifrons (White, 1847) & AJ784028 \\
\hline & Metopograpsus quadridentatus Stimpson, 1858 & DQ062732 \\
\hline & Metopograpsus thukuhar (Owen, 1839) & AJ784027 \\
\hline & Pachygrapsus crassipes Randall, 1840 & AB197814 \\
\hline & *Pachygrapsus fakaravensis Rathbun, 1907 & FR871306 \\
\hline & *Pachygrapsus gracilis (Saussure, 1858) & FR871303 \\
\hline & Pachygrapsus marmoratus (Fabricius, 1787) & DQ079728 \\
\hline & Pachygrapsus minutus A. Milne-Edwards, 1873 & $\mathrm{AB} 057808$ \\
\hline & *Pachygrapsus plicatus (H. Milne Edwards, 1837) & FR871310 \\
\hline & Pachygrapsus transversus (Gibbes, 1850) & AJ250641 \\
\hline & Planes minutus (Linnaeus, 1758) & AJ250653 \\
\hline Heloeciidae & *Heloecius cordiformis (H. Milne Edwards, 1837) & AM180695 \\
\hline \multirow[t]{2}{*}{ Macrophthalmidae } & *Macrophthalmus crinitus Rathbun, 1913 & AB537376 \\
\hline & *Hemiplax hirtipes (Jacquinot, in Hombron \& Jacquinot, 1846) & AB440189 \\
\hline \multirow[t]{2}{*}{ Mictyridae } & Mictyris brevidactylus Stimpson, 1858 & AB002133 \\
\hline & *Mictyris guinotae Davie, Shih \& Chan, 2010 & AB513632 \\
\hline \multirow[t]{4}{*}{ Ocypodidae } & *Ocypode quadrata (Fabricius, 1787) & FN539018 \\
\hline & *Uca borealis Crane, 1975 & AB535403 \\
\hline & *Uca tetragonon (Herbst, 1790) & AB535405 \\
\hline & *Ucides cordatus (Linneaus, 1763) & FN539019 \\
\hline Palicidae & Palicus caronii (Roux, 1828) & AM180692 \\
\hline \multirow[t]{2}{*}{ Percnidae } & Percnon gibbesi (H. Milne Edwards, 1853) & AJ130803 \\
\hline & *Percnon guinotae Crosnier, 1965 & FN539015 \\
\hline \multirow[t]{3}{*}{ Pinnotheridae } & Austinixa aidae (Righi, 1967) & AF503185 \\
\hline & Austinixa patagoniensis (Rathbun, 1918) & AF503186 \\
\hline & Pinnotheres pisum (Linnaeus, 1767) & AM180694 \\
\hline
\end{tabular}


Table 1. (continued)

\begin{tabular}{|c|c|c|}
\hline Family & Species & GenBank No. \\
\hline \multirow{3}{*}{ Plagusiidae } & Euchirograpsus americanus A. Milne-Edwards, 1880 & AJ250648 \\
\hline & *Plagusia depressa (Fabricius, 1775) & AJ250649 \\
\hline & Plagusia squamosa (Herbst, 1790) & AJ311796 \\
\hline \multirow[t]{2}{*}{ Potamidae } & Geothelphusa pingtung Tan \& Liu, 1998 & AB266168 \\
\hline & *Potamon potamios (Olivier, 1804) & AB428515 \\
\hline Potamonautidae & *Potamonautes perlatus (H. Milne Edwards, 1837) & AM234647 \\
\hline Pseudothelpusidae & Epilobocera sinuatifrons (A. Milne-Edwards, 1866) & FM208778 \\
\hline \multirow[t]{5}{*}{ Sesarmidae } & Armases elegans (Herklots, 1851) & AJ784011 \\
\hline & *Chiromantes haematocheir (De Haan, 1833) & AJ308414 \\
\hline & Sarmatium striaticarpus Davie, 1992 & AM180680 \\
\hline & Sesarma meridies Schubart \& Koller, 2005 & AJ621819 \\
\hline & *Sesarma reticulatum (Say, 1817) & AJ225867 \\
\hline \multirow[t]{9}{*}{ Varunidae } & Austrohelice crassa (Dana, 1851) & AJ308416 \\
\hline & Brachynotus atlanticus Forest, 1957 & AJ278831 \\
\hline & Cyrtograpsus affinis Dana, 1851 & AJ130801 \\
\hline & Eriocheir sinensis $\mathrm{H}$. Milne Edwards, 1853 & AJ250642 \\
\hline & Helograpsus haswellianus (Whitelegge, 1899) & AJ308417 \\
\hline & Hemigrapsus sanguineus (De Haan, 1835) & AJ493053 \\
\hline & Paragrapsus laevis (Dana, 1851) & AJ308418 \\
\hline & Pseudogaetice americanus (Rathbun, 1923) & AJ250643 \\
\hline & Varuna litterata (Fabricius, 1798) & AJ308419 \\
\hline \multirow[t]{2}{*}{ Xenograpsidae } & *Xenograpsus ngatama McLay, 2007 & FM863828 \\
\hline & *Xenograpsus testudinatus Ng, Huang \& Ho, 2000 & FM863827 \\
\hline Xenophthalmidae & *Xenophthalmus pinnotheroides White, 1846 & EU934951 \\
\hline
\end{tabular}

Natuurlijke Historie, collection coded as RMNH.Crus.D). The specimen of $C$. coralliodytes (made available by Dr Danièle Guinot) was collected in New Caledonia, more material of the same series is in the collections of the Muséum national d'Histoire naturelle (Paris).

\section{Analyses}

DNA was isolated from muscle tissue of the fifth pereiopod, using the Qiagen DNeasy ${ }^{\circledR}$ Kit according to the manufacturer's protocol for animal tissue. Maceration took place overnight for $\sim 18 \mathrm{~h}$. The final elution step was performed with $100 \mu \mathrm{L}$ elution buffer. PCR was carried out with standard conditions $(2.5 \mu \mathrm{L}$ PCR buffer, $0.5 \mu \mathrm{L}$ DNTPs, $1.0 \mu \mathrm{L}$ of primers $16 \mathrm{~L} 2$ and $16 \mathrm{H} 10$ (Schubart 2009), 0.3 $\mu \mathrm{L}$ Taq, 18.7 $\mu \mathrm{L}$ MilliQ and 1.0 $\mu \mathrm{L}$ DNA template). Thermal cycling was performed as follows: initial denaturation at $95^{\circ} \mathrm{C}$ for five minutes, followed by 39 cycles of $95^{\circ} \mathrm{C}$ for five seconds, $47^{\circ} \mathrm{C}$ for one minute, and $72^{\circ} \mathrm{C}$ for one minute and finalised by $10 \mathrm{~min}$ at $72^{\circ} \mathrm{C}$. Sequences were assembled and edited in Sequencer 4.10.1.

The alignment was constructed with Clustal X (Larkin et al. 2007) and minimally modified by hand. It includes 82 sequences consisting of 589 basepairs, of which 374 are variable and 319 are parsimony informative. A model selection analysis was carried out to select the best-fit model based on the Akaike Information Criterion (AIC) in jModelTest 2.1.1 (Darriba et al. 2012), which rendered $\operatorname{TrN}+\mathrm{I}+\mathrm{G}$ as the best model. A Bayesian phylogeny was estimated with MrBayes 3.1.2 (Ronquist and Huelsenbeck 2003) using the next most complex GTR $+\mathrm{I}+\mathrm{G}$ model. Four Markov-Monte-Carlo chains were run for 3000000 generations with a sample tree saved every 1000 generations (outgroup Palicus caronii). The split frequency of the likelihood scores was 0.01042 . The burnin was set to discard the first $25 \%$ of the sampled trees. The consensus tree, constructed using the 'sumt' option in MrBayes, was visualised using FigTree 1.3.1. (Rambaut 2009).

\section{Results}

The topology of Fig. 2 is derived from the Bayesian inference $50 \%$ majority rule consensus of the trees remaining after the burnin, with high support values in the basal part as well as in the distal phylogenetic branches. The outgroup is separated by a long branch, whereas the freshwater crabs from four families form a sister clade to the highly supported monophyletic Thoracotremata. Within the Thoracotremata, four major clades can be distinguished. The cryptochirid taxa included in the analyses form a monophyletic clade with a long branch length compared to the other clades. Within this highly supported clade, Utinomiella dimorpha, Pseudocryptochirus viridis and Opecarcinus lobifrons hold a basal position with respect to the remaining gall crabs. Our specimen of $H$. marsupialis differs from the specimens used in Wetzer et al. (2009) by 15-17 basepairs (bp) out of $533 \mathrm{bp}$. Nevertheless, Hapalocarcinus marsupialis is for now regarded a single species, but may well be a complex of species (see also Castro 2011).

A second clade contains Glyptograpsidae, Heloeciidae, Pinnotheridae, Ocypodidae and Sesarmidae. Ocypodidae and Pinnotheridae together form a paraphyletic clade. The single representative of the Heloeciidae appears as a sister group of the Glyptograpsidae. All Sesarmidae taxa form a monophyletic clade. A third clade is formed by the Macrophthalmidae and Varunidae. The Macrophthalmidae are polyphyletic, while the Varunidae are paraphyletic because of non-reciprocal monophyly 


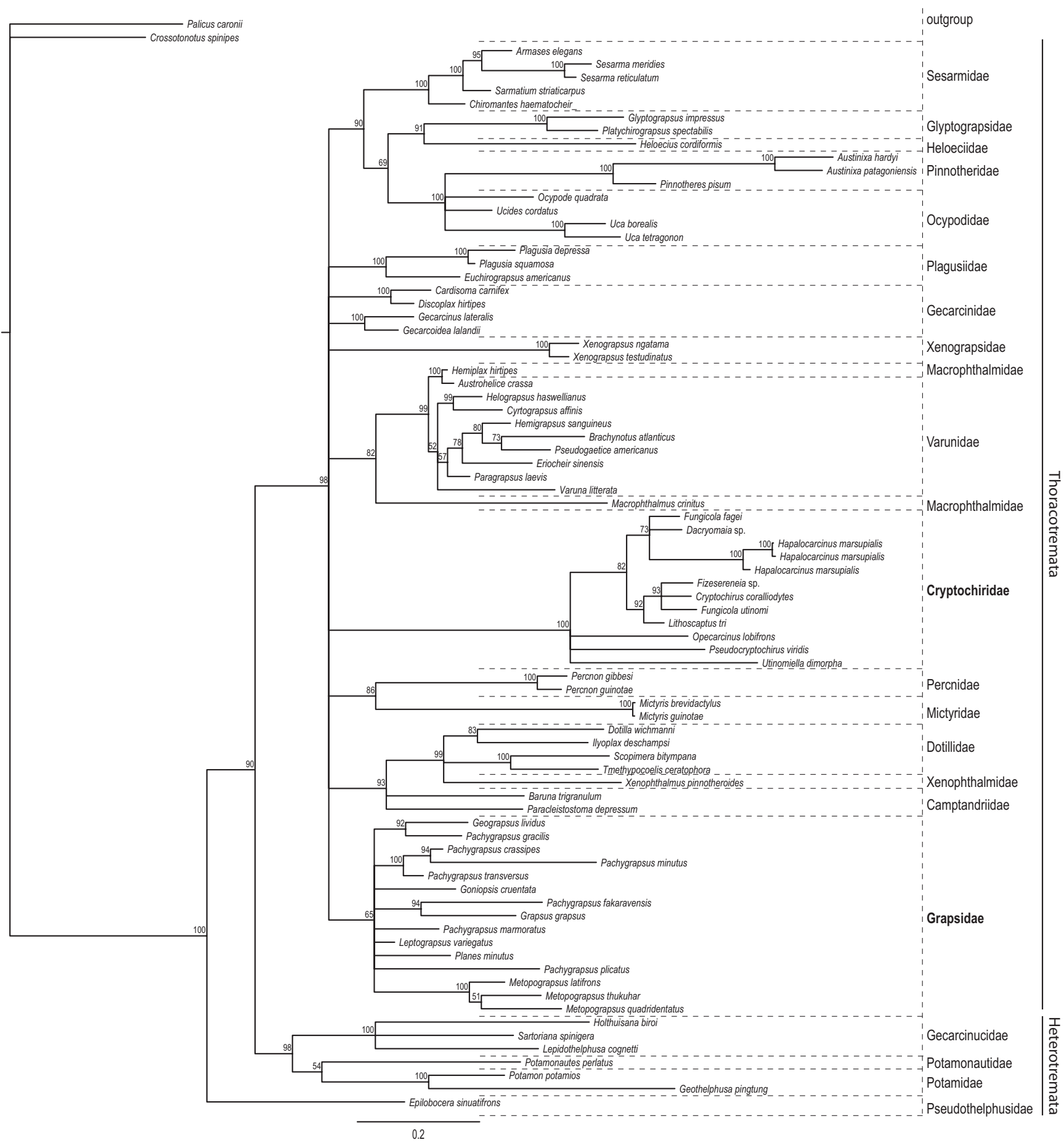

Fig. 2. Phylogenetic placement of the Cryptochiridae within the Thoracotremata, based on $16 \mathrm{~S}$ mtDNA sequences of 82 taxa (including outgroups). This tree is rooted with Palicus caronii. Topology derived from Bayesian inference 50\% majority rule, significance values are posterior probabilities.

(overlapping taxa) between these two families. Lastly, Grapsidae form the fourth monophyletic clade. The genus Pachygrapsus is paraphyletic, and the genus Metopograpsus clusters basally compared to the other grapsids. In addition to these major clades, several monophyletic families can be discerned based on our taxon sampling: the Mictyridae, Percnidae, Plagusiidae and Xenograpsidae. The Xenophthalmidae (represented by only one species) are included in the Dotillidae, which is a sister group of the Camptandriidae. The Gecarcinidae do not cluster together.

\section{Discussion}

The present molecular phylogeny, including 16S mtDNA of ten cryptochirid species belonging to nine genera, showed that 
Cryptochiridae form a highly supported monophyletic clade within the Thoracotremata with an unquestionable posterior probability of $100 \%$. Within the Cryptochiridae, representatives of Utinomiella, Pseudocryptochirus and Opecarcinus cluster basally to the other included genera. These remaining genera form one clade, with three possible subclades. Hapalocarcinus clusters weakly with Fungicola fagei and Dacryomaia sp., but with a long branch. Our results are largely in agreement with Van der Meij and Reijnen (2014), who, based on 16S and COI mtDNA, retrieved Utinomiella as the basal genus to all other cryptochirids. They also found Pseudocryptochirus forming a well supported clade with Neotroglocarcinus, and Opecarcinus forming a highly supported clade with Pseudohapalocarcinus. In their study, the remaining six genera (seven species) formed a fourth clade, with Hapalocarcinus weakly clustering as a sister clade. The position of Hapalocarcinus within the Cryptochiridae therefore remains unclear to some degree.

According to our phylogeny, gall crabs should not be considered 'highly modified Grapsidae' (see Wetzer et al. 2009), but an independent lineage deserving its current family rank. The conclusion that gall crabs are highly modified grapsids was based on low bootstrap (53\%) and posterior probability $(58 \%)$ values supporting the inclusion of $H$. marsupialis in the Grapsidae. Here we show that the conclusions of Wetzer et al. (2009) would have been different if there was better cryptochirid sampling. This may also be the case in the recent study by Tsang et al. (2014), where again only one cryptochirid taxon was used for a multi-gene phylogenetic analysis. In this case, Dacryomaia sp. is found in an unsupported sister taxon relationship with the family Xenograpsidae. It shows that conclusions on the phylogenetic position of (non-monotypic) families or other higher taxa, may be premature if based on a single species, especially when representatives are chosen that are not the type species of a genus, and when no information is available on the monophyly of the respective taxa.

Our results, and the ones by Tsang et al. (2014), do confirm the conclusion by Wetzer et al. (2009) that the Cryptochiridae belong to the Thoracotremata. In our analysis cryptochirids are consistently nested with thoracotreme crabs, when different heterotreme species were added to the dataset or used as outgroups. Yet, no clear affinities with a particular thoracotreme family could be identified. Thoracotreme crabs inhabit a wide diversity of habitats. Paulay and Starmer (2011) postulated that Thoracotremata evolved in 'safe places', such as intertidal, non-marine, deep water and endo-symbiotic habitats. Several thoracotreme families consist mainly of intertidal or shore crabs (e.g. Grapsidae, Sesarmidae, some Varunidae) occurring in different habitats, with some of them being specialised mangrove and mudflat dwellers (Camptandriidae, most Sesarmidae and Ocypodidae, with the exception of Ocypode, which specialises on sandy shores) or freshwater-dependent crabs (Glyptograpsidae and some Varunidae) (Schubart et al. 2002). Xenograpsidae with the genus Xenograpsus are specialised on hydrothermal vents (Ng et al. 2007) and many Sesarmidae and Gecarcinidae have invaded repeatedly terrestrial and/or freshwater habitats (Schubart et al. 2000). Only the Pinnotheridae have a similar lifestyle to the Cryptochiridae, by living in a permanent symbiosis with bivalves and ascidians
(Becker et al. 2011). Survival and diversification of thoracotreme crabs might therefore be related to their adaptability to new environments (Paulay and Starmer 2011).

The branch support at the family/genus level is high for most clades. One of the largest clades is formed by the Glyptograpsidae, Heloeciidae, Ocypodidae, Pinnotheridae and Sesarmidae. A possible phylogenetic relationship between the Glyptograpsidae and Sesarmidae (see Schubart et al. 2000; Wetzer et al. 2009) or Glyptograpsidae and Ocypodidae (see Schubart and Cuesta 2010) had previously been proposed based on the same gene (in addition to histone H3 in Schubart and Cuesta 2010). However, a close affinity between these families was not confirmed by the study of Palacios-Theil et al. (2009). There is ongoing debate about the phylogenetic affinities of the genus Ucides (e.g. Ng et al. 2008; Schubart and Cuesta 2010). In our analyses, the relationship of $U$. cordatus with regards to the ocypodid genera Ocypode and Uca and the Pinnotheridae is not resolved. A study on the morphology of the female reproductive system shows that the overall anatomy of $U$. cordatus is similar to other ocypodids (Castilho-Westphal et al. 2013). For now, we therefore continue to recognise Ucides as a genus within the Ocypodidae (see also Schubart and Cuesta 2010) and not in its own family as suggested by Ng et al. (2008).

The Grapsidae form a monophyletic family. The separate clustering of the genus Metopograpsus within the Grapsidae has been shown before (e.g. Kitaura et al. 2002; Wetzer et al. 2009). In Schubart et al. (2006) and Schubart (2011), Metopograpsus holds a basal position within the Grapsidae in analyses carried out with the same molecular marker. The genus Pachygrapsus appears to be polyphyletic in this study, confirming results from Schubart (2011).

Kitaura et al. (2002) and Schubart et al. (2006) proposed that the Macrophthalmidae and Varunidae are sister groups, but with low confidence values. Our phylogeny shows a closer relationship between selected Macrophthalmidae and Varunidae, with high support levels. The species Hemiplax hirtipes clusters with the Varunidae (see also Kitaura et al. 2010; McLay et al. 2010). If $H$. hirtipes would be included in the Varunidae, then this family could again be considered monophyletic (see previous work by Schubart et al. 2002), based on the included taxa. The Mictyridae appears related to the Percnidae (but with very long branches), which is a new and unexpected hypothesis considering the large phylogenetic distance between these two families in the trees of Schubart et al. (2006) and Wetzer et al. (2009). In their study on the Plagusiidae and Percnidae, Schubart and Cuesta (2010) did not include species belonging to the Mictyridae; there the genus Percnon holds a basal position to other thoracotreme families. In our tree, the Thoracotremata form a polytomy and thus no basal lineage can be postulated.

In Wetzer et al. (2009), the Camptandriidae are polyphyletic: Paracleistostoma depressum clusters as a sister group to the Mictyridae and the Pinnotheridae, whereas Baruna triganulum clusters with the Dotillidae. In our results both species form a clade with the Dotillidae. The species Xenophthalmus pinnotheroides stands together with the Dotillidae. Based on molecular data and larval morphology, Palacios-Theil et al. (2009) also suggest a close relationship of Xenophthalmus pinnotheroides with the family Dotillidae. $\mathrm{Ng}$ et al. (2008) already discussed the strange position of the Xenophthalmidae 
and found that it resembles the Dotillidae, but some characters argue against lumping them into the family. Hence they followed Serène and Umali (1972), and treated it as a good family. As the Xenophthalmidae and the Heloeciidae are represented by single species in this study, no overall conclusions about their position in the Thoracotremata should be drawn.

Overall, several phylogenetic relationships (HeloeciidaeGlyptograpsidae, Varunidae-Macrophthalmidae, PinnotheridaeOcypodidae) argue against the classical and current $(\mathrm{Ng}$ et al. 2008) superfamily concept within the Thoracotremata. Therefore, Schubart et al. (2006) suggested to refrain from this superfamily concept and treat the constituent families separately until a clearer picture of phylogenetic relationships within the Thoracotremata has been reached. The unsuitability of the current superfamilies has been re-confirmed by Schubart and Cuesta (2010) and Tsang et al. (2014). Here again we argue against it and would hence propose to refrain from using the superfamily Cryptochiroidea (see $\mathrm{Ng}$ et al. 2008), until the evolutionary origin of Cryptochiridae (and taxonomic classification reflecting it) is better understood.

In summary, the Cryptochiridae is a highly enigmatic family, for which the closest relatives so far remain unknown. The present study is based on a single gene fragment, and additional support needs to be obtained from independent molecular markers. Further studies on the evolution of Cryptochiridae within the Thoracotremata should for that reason be based on multiple markers, to obtain more insight in their unusual biology and life history.

\section{Acknowledgements}

We are indebted to Dr Danièle Guinot (MNHN) for making available a museum specimen of Cryptochirus coralliodytes, Bastian Reijnen (Naturalis) for assistance with the laboratory work, Theodor Poettinger (Universität Regensburg) for help with software, and Dr Roy Kropp for discussions in an earlier stage of this manuscript. The fieldwork in Indonesia was jointly organised by Dr Bert W. Hoeksema (Naturalis) and Mrs. Yosephine Tuti (RCO-LIPI), while the research permits were granted by LIPI (Raja Ampat) and RISTEK (Ternate). Funding for the fieldwork in Indonesia was provided by the A.M. Buitendijkfonds, and L.B. Holthuisfonds (both Naturalis), Leiden University Funds, Schure-Beijerinck-Popping Fund, and the Stichting Fonds Doctor Catharine van Tussenbroek (Nell Ongerboerfonds). The 2010 Semporna Marine Ecological Expedition (SMEE2010) was jointly organised by WWF-Malaysia, Universiti Malaysia Sabah's Borneo Marine Research Institute, Universiti Malaya's Institute of Biological Sciences and Naturalis Biodiversity Center, and funded through WWF-Malaysia. Research permits were granted by the Prime Minister's Department, Economic Planning Unit Sabah, Sabah Parks and Department of Fisheries Sabah. We thank two anonymous reviewers for their comments and suggestions on an earlier version of the manuscript.

\section{References}

Ahyong, S. T., Lowry, J. K., Alonso, M., Bamber, R. N., Boxshall, G. A., Castro, P., Gerken, S., Karaman, G. S., Goy, J. W., Jones, D. S., Meland, K., Rogers, D. C., and Svavarsson, J. (2011). Subphylum Crustacea Brünnich, 1772. In 'Animal Biodiversity: An Outline of Higher-level Classification and Survey of Taxonomic Richness'. (Ed. Z.-Q. Zhang.) Zootaxa 3148, 165-191.

Becker, C., Brandis, D., and Storch, V. (2011). Morphology of the female reproductive system of European pea crabs (Crustacea, Decapoda, Brachyura, Pinnotheridae). Journal of Morphology 272, 12-26. doi:10.1002/jmor.10884
Castilho-Westphal, G. G., Ostrensky, A., Pie, M. R., and Boeger, W. A. (2013). Morphology of the female reproductive system and reproductive cycle of the mangrove land crab Ucides cordatus (L.) in the Baía de Antonina, Paraná, Brazil. Acta Zoologica 94, 86-93. doi:10.1111/ azo. 12000

Castro, P. (2011). Catalog of the anomuran and brachyuran crabs (Crustacea: Decapoda: Anomura, Brachyura) of the Hawaiian Islands. Zootaxa 2947, $1-154$.

Darriba, D., Taboada, G. L., Doallo, R., and Posada, D. (2012). jModelTest 2: more models, new heuristics and parallel computing. Nature Methods $\mathbf{9}$, 772. doi:10.1038/nmeth.2109

Davie, P. (2014). Cryptochiridae Paul'son, 1875. Accessed through: World Register of Marine Species at http://www.marinespecies.org/aphia.php? $\mathrm{p}=$ taxdetails\&id $=106753$ [accessed 22 October 2014]

De Grave, S., Pentcheff, N. D., Ahyong, S. T., Chan, T.-Y., Crandall, K. A., Dworschak, P. C., Felder, D. L., Feldmann, R. M., Fransen, C. H. J. M., Goulding, L. Y. D., Lemaitre, R., Low, M. E. Y., Martin, J. W., Ng, P. K. L., Schweitzer, C. E., Tan, S. H., Tshudy, D., and Wetzer, R. (2009). A classification of living and fossil genera of decapod crustaceans. The Raffles Bulletin of Zoology 21(Supplement), 1-109.

de Haan, W. (1833-1850). Crustacea. In 'Fauna Japonica sive Descriptio Animalium, Quae in Itinere per Japoniam, Jussu et Auspiciis Superiorum, qui Summum in India Batava Imperium Tenent, Suscepto, Annis 1823-1830 Collegit, Noitis, Observationibus et Adumbrationibus Illustravit'. (Ed. P. F. von Siebold.) (Lugduni-Batavorum: Leiden.) pp. i-xvii, i-xxxi, ix-xvi, 1-243, Plates A-J, L-Q, 1-55, circ. Table 2.

Fize, A. (1956). Observations biologiques sur les Hapalocarcinidés. Annales de la Faculté des Sciences (Université Nationale du Viêt-Nam, Contribution no. 22 de l'Institut Océanographique de Nhatrang) 22, 1-30.

Fize, A. and R. Serène. (1957). Les Hapalocarcinides du Viet-Nam. Mémoires de l'Institut Océanographique de Nhatrang 10, 1-202, pls. 1-18.

Guinot, D. (1977). Propositions pour une nouvelle classification des Crustacés Décapodes Brachyoures. Comptes rendus hebdomadaires des séances de l'Académie des sciences, série D 285, 1049-1052.

Guinot, D., and Bouchard, J.-M. (1998). Evolution of the abdominal holding systems of brachyuran crabs (Crustacea, Decapoda, Brachyura). Zoosystema 20, 613-694.

Guinot, D., and Richer de Forges, B. (1997). Affinités entre les Hymenosomatidae MacLeay, 1838 et les Inachoididae Dana, 1851 (Crustacea, Decapoda, Brachyura). Zoosystema 19, 453-502.

Guinot, D., Tavares, M., and Castro, P. (2013). Significance of the sexual openings and supplementary structures on the phylogeny of brachyuran crabs (Crustacea, Decapoda, Brachyura), with new nomina for higherranked podotreme taxa. Zootaxa 3665, 1-414. doi:10.11646/zootaxa. 3665.1 .1

Heller, C. (1861). Beiträge zur Crustaceen-Fauna des Rothen Meeres. I. Theil. Sitzungsberichte der Mathematisch-Naturwissenschaftlichen Klasse der Kaiserlichen Akademie der Wissenschaften, Wien 43, 297-374.

Jamieson, B. G. M., and Tudge, C. C. (2000). Crustacea - Decapoda. In 'Reproductive Biology of Invertebrates. Volume IX, Part C. Progress in Male Gamete Ultrastructure and Phylogeny'. (Ed. B. G. M. Jamieson.) pp. 1-95. (John Wiley and Sons: Chichester, UK.)

Kitaura, J., Wada, K., and Nishida, M. (2002). Molecular phylogeny of grapsoid and ocypodoid crabs with special reference to the genera Metaplax and Macrophthalmus. Journal of Crustacean Biology 22, 682-693. doi:10.1163/20021975-99990281

Kitaura, J., Wada, K., Fukui, Y., and McLay, C. L. (2010). Molecular phylogenetic position of the New Zealand sentinel crab, Macrophthalmus (Hemiplax) Hirtipes (Jacquinot, in Hombron and Jacquinot, 1846) (Decapoda, Brachyura, Macrophthalmidae). Crustaceana 83, 1315-1326. doi:10.1163/001121610X533548

Klaus, S., Brandis, D., Ng, P. K. L., Yeo, D. C. J., and Schubart, C. D. (2009). Phylogeny and biogeography of Asian freshwater crabs of the family Gecarcinucidae (Brachyura: Potamoidea). In 'Crustacean Issues 18: 
Decapod Crustacean Phylogenetics'. (Eds J. W. Martin, K. A. Crandall, and D. L. Felder.) pp. 509-531. (CRC Press: Boca Raton, FL.)

Kropp, R. K. (1988). Biology and systematics of coral gall crabs (Crustacea: Cryptochiridae). PhD Thesis, University of Maryland, College Park, MD.

Kropp, R. K. (1989). A revision of the Pacific species of gall crabs, genus Opecarcinus (Crustacea: Cryptochiridae). Bulletin of Marine Science 45, 98-129.

Kropp, R. K. (1990). Revision of the genera of gall crabs (Crustacea: Cryptochiridae) occurring in the Pacific Ocean. Pacific Science 44, 417-448.

Kropp, R. K., and Manning, R. B. (1985). Cryptochiridae, the correct name for the family containing the gall crabs (Crustacea: Decapoda: Brachyura). Proceedings of the Biological Society of Washington 98, 954-955.

Kropp, R. K., and Manning, R. B. (1987). The Atlantic gall crabs, family Cryptochiridae (Crustacea: Decapoda: Brachyura). Smithsonian Contributions to Zoology 462, 1-21. doi:10.5479/si.00810282.462

Larkin, M. A., Blackshields, G., Brown, N. P., Chenna, R., McGettigan, P. A., McWilliam, H., Valentin, F., Wallace, I. M., Wilm, A., Lopez, R., Thompson, J. D., Gibson, T. J., and Higgins, D. G. (2007). Clustal W and Clustal X version 2.0. Bioinformatics 23, 2947-2948. doi:10.1093/ bioinformatics $/ \mathrm{btm} 404$

MacLeay, W. S. (1838). On the brachyurous decapod Crustacea brought from the Cape by Dr. Smith. In: Smith, A. (ed.) Illustrations of the Annulosa of South Africa; being a portion of the objects of natural history chiefly collected during an expedition into the interior of South Africa, under the directin of Dr. Andrew Smith, in the years 1834, 1835 and 1836; fitted out by "The Cape of Good Hope Association for Exploring Central Africa". London: Smith, Elder, and Co. Pp. 53-71, 2 plates.

Martin, J. W., and Davis, G. E. (2001). An updated classification of the Recent Crustacea. Natural History Museum of Los Angeles County. Science Series 39, 1-124.

McLay, C. L., Kitaura, J., and Wada, K. (2010). Behavioural and molecular evidence for the systematic position of Macrophthalmus (Hemiplax) hirtipes Hombron and Jacquinot, 1846, with comments on macrophthalmine subgenera. Crustaceana Monographs 14, 483-503.

Milne-Edwards, A. (1862). Faune carcinologique de l'île de la Réunion. In: Maillard, L. (ed.) Notes sur l'île de la Réunion. Vol. Annexe F. Paris. pp. $1-16$.

Ng, N. K., Davie, P. J. F., Schubart, C. D., and Ng, P. K. L. (2007). Xenograpsidae, a new family of grapsoid crabs (Crustacea: Brachyura) associated with shallow water hydrothermal vents. The Raffles Bulletin of Zoology 16(Supplement), 233-256.

Ng, P. K. L., Guinot, D., and Davie, P. J. F. (2008). Systema Brachyurorum: Part 1. An annotated checklist of extant brachyuran crabs of the world. The Raffles Bulletin of Zoology 17(Supplement), 1-286.

Palacios-Theil, E., Cuesta, J. A., Campos, E., and Felder, D. L. (2009). Molecular genetic re-examination of subfamilies and polyphyly in the family Pinnotheridae (Crustacea: Decapoda). In 'Crustacean Issues 18: Decapod Crustacean Phylogenetics'. (Eds J. W. Martin, K. A. Crandall and D. L. Felder.) pp. 457-474. (CRC Press: Boca Raton, FL.)

Paulay, G., and Starmer, J. (2011). Evolution, insular restriction, and extinction of oceanic land crabs, exemplified by the loss of an endemic Geograpsus in the Hawaiian Islands. PLoS ONE 6, e19916.

Paul'son, O. (1875). Studies on Crustacea of the Red Sea with notes regarding other seas. Part I. Podophthalmata and Edriophthalmata (Cumacea). [In Russian, English translation by the Israel Program for Scientific Translations, Jerusalem, 1961]. Kiev: S.V. Kul'zhenko. xiv, 144 pp, Plates 1-22.

Rambaut, A. (2009). FigTree, ver. 1.3.1. [Online]. Available at http://tree.bio. ed.ac.uk/software/figtree/ [verified September 2014]

Richters, F. (1880). Decapoda. In 'Beiträge zur Meeresfauna der Insel Mauritius und der Seychellen bearbeitet von K. Möbius, F. Richters und E. von Martens nach Sammlungen, angelegt auf einer Reise nach
Mauritius von K. Möbius'. (Ed. K. Möbius) pp. 139-178, plates XV-XVIII. (Verlag der Gutmann'schen Buchhandlung: Berlin.)

Ronquist, F., and Huelsenbeck, J. P. (2003). MrBayes 3: Bayesian phylogenetic inference under mixed models. Bioinformatics 19, 1572-1574. doi:10.1093/bioinformatics/btg 180

Schubart, C. D. (2009). Mitochondrial DNA and decapod phylogenies: the importance of pseudogenes and primer optimization. In 'Crustacean Issues 18: Decapod Crustacean Phylogenetics'. (Eds J. W. Martin, K. A. Crandall and D. L. Felder.) pp. 47-65. (CRC Press: Boca Raton, FL.)

Schubart, C. D. (2011). Reconstruction of phylogenetic relationships within Grapsidae (Crustacea: Brachyura) and comparison of trans-isthmian versus amphi-atlantic gene flow based on mtDNA. Zoologischer Anzeiger 250, 472-478. doi:10.1016/j.jcz.2011.06.003

Schubart, C. D., and Cuesta, J. A. (2010). Phylogenetic relationships of the Plagusiidae Dana, 1851, (Brachyura) with description of a new genus and recognition of Percnidae Števčić, 2005, as an independent family. In 'Studies on Brachyura: a Homage to Danièle Guinot'. (Eds P. Castro, P. J. F. Davie, P. K. L. Ng and B. Richer de Forges.) Crustaceana Monographs 11, 279-299.

Schubart, C. D., and Koller, P. (2005). Genetic diversity of freshwater crabs (Brachyura: Sesarmidae) from central Jamaica with description of a new species. Journal of Natural History 39, 469-481. doi:10.1080/ 00222930410001671291

Schubart, C. D., Cannicci, S., Vannini, M., and Fratini, S. (2006). Molecular phylogeny of grapsoid crabs and allies based on two mitochondrial genes and a proposal for refraining from current superfamily classification. Journal of Zoological Systematics and Evolutionary Research 44, 193-199. doi:10.1111/j.1439-0469.2006.00354.x

Schubart, C. D., Cuesta, J. A., Diesel, R., and Felder, D. L. (2000). Molecular phylogeny, taxonomy, and evolution of nonmarine lineages within the American grapsoid crabs (Crustacea: Brachyura). Molecular Phylogenetics and Evolution 15,179-190. doi:10.1006/mpev.1999.0754

Schubart, C. D., Cuesta, J. A., and Felder, D. L. (2002). Glyptograpsidae, a new brachyuran family from Central America: larval and adult morphology, and a molecular phylogeny of the Grapsoidea. Journal of Crustacean Biology 22, 28-44. doi:10.1163/20021975-99990206

Scotto, L. E., and Gore, R. H. (1981). Studies on decapod Crustacea from the Indian River region of Florida. 23. The laboratory cultured zoel stages of the coral gall-forming crab Troglocarcinus corallicola Verrill, 1908 (Brachyura, Haplocarcinidae) and its familial position. Journal of Crustacean Biology 1, 486-505. doi:10.2307/1548126

Serène, R., and Umali, A. F. (1972). The family Raninidae and other new and rare species of Brachyuran Decapods from the Philippines and adjacent regions. Philippine Journal of Science 99, 21-105.

Stimpson, W. (1859). Proceedings of the Boston Society of Natural History 6, 412-413. [Untitled report on: “...a remarkable new form of brachyurous crustacean on the coral reefs at Hawaii."]

Tsang, L. M., Schubart, C. D., Ahyong, S. T., Lai, J. C. Y., Au, E. Y. C., Chan, T.-Y., Ng, P. K. L., and Chu, K. H. (2014). Evolutionary history of true crabs (Crustacea: Decapoda: Brachyura) and the origin of freshwater crabs. Molecular Biology and Evolution 31, 1173-1187. doi:10.1093/ molbev/msu068

Tudge, C. C., Scheltinga, D. M., Jamieson, B. G. M., Guinot, D., and Richer de Forges, B. (2014). Comparative ultrastructure of the spermatozoa of the Majoidea (Crustacea, Decapoda, Brachyura) with new data on six species in five genera. Acta Zoologica 95, 1-20. doi:10.1111/azo.12005

Utinomi, H. (1944). Studies on the animals inhabiting reef corals. III. A revision of the family Hapalocarcinidae (Brachyura), with some remarks on their morphological peculiarities. Palao Tropical Biological Station Studies 2, 687-731, pls. 3-5.

van der Meij, S. E. T. (2012). Host preferences, colour patterns and distribution records of Pseudocryptochirus viridis Hiro, 1938 (Decapoda, Cryptochiridae). Crustaceana 85, 769-777. doi:10.1163/ 156854012 X650223 
van der Meij, S. E. T., and Reijnen, B. T. (2014). The curious case of Neotroglocarcinus dawydoffi (Decapoda, Cryptochiridae): unforeseen biogeographic patterns resulting from isolation. Systematics and Biodiversity 12, 503-512. doi:10.1080/14772000.2014.946979

Vehof, J., van der Meij, S. E. T., Türkay, M., and Becker, C. (in press). Female reproductive morphology of coral-inhabiting gall crabs (Crustacea: Decapoda: Brachyura: Cryptochiridae). Acta Zoologica.

Verrill, A. E. (1908). Decapod Crustacea of Bermuda; I - Brachyura and Anomura. Their distribution, variations, and habits. Transactions of the
Connecticut Academy of Arts and Sciences 13, 299-473. [Plates IX-XXVIII.]

Wetzer, R., Martin, J. W., and Boyce, S. L. (2009). Evolutionary origin of the gall crabs (family Cryptochiridae) based on 16S rDNA sequence data. In 'Crustacean Issues 18: Decapod Crustacean Phylogenetics'. (Eds J. W. Martin, K. A. Crandall and D. L. Felder.) pp. 475-490. (CRC Press: Boca Raton, FL.) 